\title{
Synthesis, Structural Diversity and Mimic Superoxide Dismutase of Mn(II) Complexes Derived from N, O-donor Schiff bases
}

\author{
Jie Qin,* Qiang Yin, Shan-Shan Zhao, Jun-Zheng Wang and Shao-Song Qian*
}

\author{
School of Life Sciences, Shandong University of Technology, Zibo 255049, P. R. China \\ * Corresponding author: E-mail: qinjietutu@163.com, sdutqss@163.com \\ Tel.: 0086-533-2780271; Fax: 0086-533-2781329
}

Received: 18-08-2015

\begin{abstract}
Two new potentially tetradentate Schiff base ligands $N^{\prime}$-(pyridin-2-ylmethylene)nicotinohydrazide $\left(L_{1}\right)$, and $N^{\prime}$-(pyridin-2-ylmethylene)isonicotinohydrazide $\left(L_{2}\right)$ were synthesized. Reactions of hydrazone ligands $L_{1}$ and $L_{2}$ with $\mathrm{Mn}\left(\mathrm{NO}_{3}\right)_{2}$ afford two mononuclear $\mathrm{Mn}(\mathrm{II})$ complexes, $\left[\mathrm{Mn}\left(L_{1}\right)\left(\mathrm{NO}_{3}\right)\left(\mathrm{H}_{2} \mathrm{O}\right)_{2}\right] \mathrm{NO}_{3}(\mathbf{1})$ and $\left[\mathrm{Mn}\left(L_{2}\right)_{2}\left(\mathrm{NO}_{3}\right)\left(\mathrm{H}_{2} \mathrm{O}\right)\right] \mathrm{NO}_{3}$ (2). For complexes $\mathbf{1}$ and 2, $L_{1}$ and $L_{2}$ act as pincer-like tridentate or bidentate ligands, respectively. The Mn(II) ions in the two compounds are both in hepta-coordinated environment, while the two molecules display diverse solid-state supramolecular structures because of the different orientation of $\mathrm{N}_{\text {pyridine }}$ and hydrogen bonding patterns of nitrate anions. Complex 1 features 2D supramolecular sheet, while complex 2 has double-chain supramolecular structure. Both of the complexes exhibit moderate superoxide dismutase (SOD) mimetic activity.
\end{abstract}

Keywords: Schiff base; Mn(II) complex; Supramolecular structure; SOD mimetic activity

\section{Introduction}

Schiff base compounds derived from the condensation reaction of aldehydes with amines are very attractive for their coordination ability to metal atoms, ${ }^{1-3}$ and excellent biological applications. ${ }^{4,5}$ Among the variety of aldehydes, salicylaldehyde derivatives are mostly used. Within this form of aldehydes, a number of bidentate NO or tetradentate $\mathrm{N}_{2} \mathrm{O}_{4}$ Schiff base ligands have been used as the building blocks to obtain a variety of coordination complexes. ${ }^{6-8}$ Aygün et al. have also reported tridentate Schiff base ligand derived from phenylalanine and 2,4-dihydroxybenzaldehyde. ${ }^{9}$ While Schiff base ligands based on pyridylaldehyde derivatives are still rare or lacking. ${ }^{10,11}$ Aroyl hydrazones are an important class of Schiff base ligands, coordinating through amide oxygen and the imine nitrogen of hydrazone moiety. ${ }^{10,12}$ Moreover, $\mathrm{N}$ and $\mathrm{O}$ heteroatoms of the aroyl hydrazones with free electron pairs can also be considered as potential hydrogen bond acceptors to expand polymeric frameworks with hydrogen-bonding interactions.

Numerous diseases, such as amyotrophic lateral sclerosis, Parkinson's disease, Alzheimer's disease are considered to be connected with the over production of superoxide radical anion. Superoxide dismutase (SOD) can accelerate the dismutation of superoxide anion into hydrogen peroxide and dioxygen, which play an important role in defending life from the diseases mentioned above. ${ }^{13}$ Three isoforms of SOD have been found, including Cu/Zn-SOD (SOD 1), Mn-SOD (SOD 2) and extracellular SOD (SOD 3). Compared with native SOD enzymes, low molecular weight SOD mimics have advantages in lack of immunogenic responses, improved access to lipid layer of the cell membrane, and low cost. ${ }^{14}$ Therefore the rational design and synthesis of SOD mimics has potential in metal-based therapeutic agents. Mn complexes derived from Schiff base, porphyrin and their derivatives have been studied as Mn-SOD mimics. ${ }^{15}$

In this contribution, we present the synthesis of two new hydrazone Schiff base ligands $N^{\prime}$-(pyridin-2ylmethylene)nicotinohydrazide $\left(L_{l}\right)$ and $N^{\prime}$-(pyridin-2ylmethylene)isonicotinohydrazide $\left(L_{2}\right)$ (see Scheme 1), and two novel mononuclear Mn(II) complexes 1 and 2 generated from these two hydrazone ligands and $\mathrm{Mn}\left(\mathrm{NO}_{3}\right)_{2}$, the structures and IR spectra, as well as the SOD mimetic activities. 


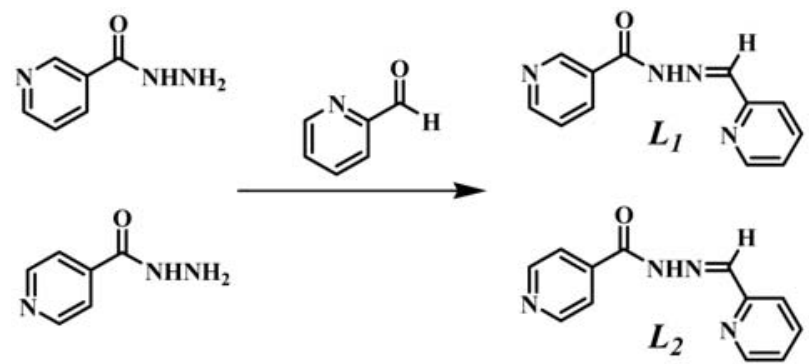

Scheme 1. Synthetic routes to hydrazone ligands.

\section{Experimental}

\section{1. Physical Measurements and Materials}

All the solvents and reagents were reagent grade and used as received. Nicotinohydrazide, isonicotinohydrazide, 2-pyridinecarboxaldehyde, and $\mathrm{Mn}\left(\mathrm{NO}_{3}\right)_{2} \cdot 4 \mathrm{H}_{2} \mathrm{O}$ were purchased from Aladdin Industrial Corporation (China). Superoxide Dismutase Assay Kit was purchased from Nanjing Jiancheng Bioengineering Insitute (China). $N$ '-(pyridin-2-ylmethylene)nicotinohydrazide $\left(L_{l}\right)$ and $N^{\prime}$-(pyridin2-ylmethylene)isonicotinohydrazide $\left(L_{2}\right)$ were synthesized according to the literature. ${ }^{16}$ The IR spectra were taken on a Vector 22 Bruker spectrophotometer $\left(400-4000 \mathrm{~cm}^{-1}\right)$ with $\mathrm{KBr}$ pellets. Elemental analyses for $\mathrm{C}, \mathrm{H}$ and $\mathrm{N}$ were performed on a Perkin-Elmer 240C analyzer. ${ }^{1} \mathrm{H}$ NMR spectra were measured on a Bruker AM 500 spectrometer.

\section{2. X-ray Crystallography}

Diffraction intensities for complexes $\mathbf{1}$ and $\mathbf{2}$ were collected at $298 \mathrm{~K}$ on a Bruker Smart Apex CCD diffractometer equipped with graphite-monochromated Mo $\mathrm{K} \alpha$ ( $\lambda=0.71073 \AA$ ) radiation using a $\omega-2 \theta$ scan mode. The collected data were reduced using the SAINT program, ${ }^{17}$ and multi-scan absorption corrections were performed using the SADABS program. ${ }^{18}$ The structures were solved by direct methods and refined based on $F^{2}$ by full-matrix least-squares methods were performed with the SHELXTL program packages. ${ }^{19}$ All non-hydrogen atoms were refined with anisotropic displacement parameters. All the hydrogen atoms bonded to $\mathrm{C}$ atoms were generated geometrically and refined isotropically using the riding model. While hydrogen atoms bond to $\mathrm{N}$ or $\mathrm{O}$ atoms were first found in the Fourier map and then fixed at their ideal positions. Water $\mathrm{H}$ atoms were refined with distance restraints of $\mathrm{O}-\mathrm{H}=0.85(1) \AA, \mathrm{H} \cdots \mathrm{H}=1.44(2) \AA$ and $U_{\text {iso }}(\mathrm{H})=1.5 U_{\text {eq }}(\mathrm{O})$. Imine $\mathrm{H}$ atoms were refined with distance restraints of $\mathrm{N}-\mathrm{H}=0.89(1) \AA$, and $U_{\text {iso }}(\mathrm{H})=$ $1.5 U_{\text {eq }}(\mathrm{N})$. In complex 2 , O5 was disordered over two positions that refined to a ratio of $0.50(4): 0.50(4)$. Further refinement details of the structural analysis for the two complexes are given in Table 1. Selected bond lengths and angles of the complexes are listed in Table 2.
Table 1. Crystallographic data for complexes $\mathbf{1}$ and $\mathbf{2}$.

\begin{tabular}{lll}
\hline & \multicolumn{1}{c}{$\mathbf{1}$} & \multicolumn{1}{c}{$\mathbf{2}$} \\
\hline Chemical formula & $\mathrm{C}_{12} \mathrm{H}_{14} \mathrm{MnN}_{6} \mathrm{O}_{9}$ & $\mathrm{C}_{24} \mathrm{H}_{22} \mathrm{MnN}_{10} \mathrm{O}_{9}$ \\
Formula Weight & 441.23 & 649.46 \\
Crystal System & Triclinic & Triclinic \\
Space group & $P^{-}$ & $P_{1}^{-}$ \\
Temperature $(\mathrm{K})$ & 298 & 298 \\
$a(\AA)$ & $8.6450(17)$ & $9.1500(4)$ \\
$b(\AA)$ & $9.5075(17)$ & $10.4018(5)$ \\
$c(\AA)$ & $10.8250(18)$ & $14.4785(6)$ \\
$\alpha\left(^{\circ}\right)$ & $82.180(5)$ & $83.173(1)$ \\
$\beta\left({ }^{\circ}\right)$ & $88.184(6)$ & $86.514(1)$ \\
$\gamma\left({ }^{\circ}\right)$ & $89.803(6)$ & $89.360(2)$ \\
$V\left(\AA^{3}\right)$ & $881.0(3)$ & $1365.70(11)$ \\
$\mathrm{Z}$ & 2 & 2 \\
$\mu(\mathrm{Mo}-\mathrm{K} \alpha)\left(\mathrm{mm}^{-1}\right)$ & 0.812 & 0.556 \\
$R_{1}, \mathrm{w} R_{2}[\mathrm{I}>2 \sigma(\mathrm{I})]$ & $0.167,1.05$ & $0.122,1.03$ \\
$\rho_{\mathrm{c}}\left(\mathrm{g} \mathrm{cm} \mathrm{cm}^{-3}\right)$ & 1.663 & 1.579 \\
$\mathrm{~F}(000)$ & 450 & 666 \\
$\mathrm{Goodness}$ of fit on $\mathrm{F}^{2}$ & 1.05 & 1.03
\end{tabular}

\section{3. Superoxide Dismutase Assay}

The SOD activity of the title complexes was studied by indirect method using Superoxide Dismutase Assay Kit according to the instruction of the manufacturer. Briefly, the xanthine-xanthine oxidase system was used for the production of superoxide. For the detection of superoxide the absorbance increases at $510 \mathrm{~nm}$ arising from the reduction of iodophenyl nitrophenyl phenyltetrazolium salt (INT). The reaction mixture contained 4.2 $\cdot 10^{-5} \mathrm{M}$ xanthine and $8.25 \cdot 10^{-5} \mathrm{M}$ INT in $0.05 \mathrm{M}$ phosphate buffer solution at $\mathrm{pH}$ 7.8. The reaction was started by the addition of xanthine oxidase in the amount needed to generate the absorbance change 0.03-0.04 $\min ^{-1}$. The SOD mimic activity of the complexes $\mathbf{1}$ and $\mathbf{2}$ was evaluated from the absorbance decrease comparing to the blank after the $10 \mathrm{~min}$ incubation at $37^{\circ} \mathrm{C}$. The $\mathrm{IC}_{50}$ value was defined as the concentration of complex $(\mu \mathrm{M})$ necessary for the $50 \%$ inhibition of the INT reduction.

\section{4. Synthesis of $\left[\mathrm{Mn}\left(L_{1}\right)\left(\mathrm{NO}_{3}\right)\left(\mathrm{H}_{2} \mathrm{O}\right)_{2}\right]$ $\mathrm{NO}_{3}(1)$}

A solution of $\mathrm{Mn}\left(\mathrm{NO}_{3}\right)_{2} \cdot 4 \mathrm{H}_{2} \mathrm{O}(16.1 \mathrm{mg}, 0.050$ $\mathrm{mmol})$ in $\mathrm{EtOH}(5 \mathrm{~mL})$ was layered onto a solution of $L_{1}$ (9.1 mg, $0.040 \mathrm{mmol}$ ) in $\mathrm{CH}_{2} \mathrm{Cl}_{2}(5 \mathrm{~mL})$. The system was left for about one week at room temperature, after which time crystals of 1 were obtained (yield 61\%). IR ( $\mathrm{KBr}$, $\left.\mathrm{cm}^{-1}\right)$ : 3350, 3220, 3066, 1648, 1598, 1556, 1495, 1474, $1443,1381,1303,1225,1158,1136,1111,1027,1010$, 959, 922, 823, 785, 735, 700, 637, 522. Anal. Calcd. for $\mathrm{C}_{12} \mathrm{H}_{14} \mathrm{MnN}_{6} \mathrm{O}_{9}(\%): \mathrm{C}, 32.67 ; \mathrm{H}, 3.19 ; \mathrm{N}, 19.05$. Found: C, 32.75; H, 3.17; N, 19.11 . 


\section{5. Synthesis of $\left[\mathrm{Mn}\left(L_{2}\right)_{2}\left(\mathrm{NO}_{3}\right)\left(\mathrm{H}_{2} \mathrm{O}\right)\right.$ $\mathrm{NO}_{3}(2)$}

Complex 2 was synthesized in an analogous manner, but using $L_{2}$ instead of $L_{l}$. Yield $53 \%$. IR $\left(\mathrm{KBr}, \mathrm{cm}^{-1}\right)$ : $3383,3178,3051,1645,1599,1553,1487,1470,1443$, 1384, 1313, 1254, 1219, 1153, 1106, 1060, 1037, 1006, 923, 850, 784, 751, 731, 692, 683, 632, 589, 522. Anal. Calcd. for $\mathrm{C}_{24} \mathrm{H}_{22} \mathrm{MnN}_{10} \mathrm{O}_{9}(\%)$ : C, 44.38; $\mathrm{H}, 3.41 ; \mathrm{N}$, 21.57. Found: C, 44.51; H, 3.39; N, 21.63.

\section{Results and Discussion}

\section{1. Synthesis}

Ligand $L_{1}$ and $L_{2}$ was synthesized by a one-pot condensation reaction of nicotinohydrazide or isonicotinohydrazide with pyridine-2-carboxaldehyde in ethanol solution at refluxing temperature, respectively. The products were washed with cold ethanol. Mononuclear metal complexes 1 and 2 were obtained by coordination of $L_{1}$ or $L_{2}$ with $\mathrm{Mn}\left(\mathrm{NO}_{3}\right)_{2} \cdot 4 \mathrm{H}_{2} \mathrm{O}$ at room temperature, respectively. Their IR and ${ }^{1} \mathrm{H}$ NMR spectra were depicted in Figures S1-S4.

Table 2. Selected bond angles $\left(^{\circ}\right)$ and bond lengths ( $(\AA)$ for $\mathbf{1}$ and $\mathbf{2}$.

\begin{tabular}{lclc}
\hline & 1 & & $\mathbf{2}$ \\
\hline Mn1-O9 & $2.178(3)$ & Mn1-O9 & $2.1666(17)$ \\
Mn1-O8 & $2.197(3)$ & Mn1-O3 & $2.228(2)$ \\
Mn1-O3 & $2.382(3)$ & Mn1-O2 & $2.2679(15)$ \\
Mn1-O2 & $2.249(3)$ & Mn1-O1 & $2.4148(16)$ \\
Mn1-O1 & $2.354(3)$ & Mn1-N6 & $2.3594(19)$ \\
Mn1-N1 & $2.333(3)$ & Mn1-N1 & $2.3915(17)$ \\
Mn1-N2 & $2.267(3)$ & Mn1-N2 & $2.2894(18)$ \\
O9-Mn1-O8 & $177.47(11)$ & O9-Mn1-O3 & $164.05(7)$ \\
O9-Mn1-N1 & $94.16(11)$ & O9-Mn1-O2 & $83.15(6)$ \\
O9-Mn1-N2 & $89.37(11)$ & O9-Mn1-O1 & $82.92(6)$ \\
O9-Mn1-O1 & $88.43(10)$ & O9-Mn1-N1 & $87.11(7)$ \\
O9-Mn1-O3 & $90.83(12)$ & O9-Mn1-N2 & $94.51(6)$ \\
O9-Mn1-O2 & $87.07(11)$ & O9-Mn1-N6 & $91.94(7)$ \\
N2-Mn1-N1 & $70.11(11)$ & O2-Mn1-N1 & $80.67(6)$ \\
N2-Mn1-O1 & $68.32(10)$ & N2-Mn1-O1 & $65.82(6)$ \\
O2-Mn1-O3 & $55.55(10)$ & N2-Mn1-N1 & $68.53(6)$ \\
O2-Mn1-O1 & $82.55(9)$ & O2-Mn1-N6 & $68.77(6)$ \\
N1-Mn1-O3 & $83.57(11)$ & O1-Mn1-N6 & $77.95(6)$ \\
O8-Mn1-N1 & $88.12(11)$ & O3-Mn1-O2 & $82.75(8)$ \\
O8-Mn1-N2 & $90.38(12)$ & O3-Mn1-N2 & $93.79(8)$ \\
O8-Mn1-O1 & $89.13(11)$ & O3-Mn1-N1 & $83.28(7)$ \\
O8-Mn1-O3 & $90.52(12)$ & O3-Mn1-O1 & $112.94(7)$ \\
O8-Mn1-O2 & $91.93(11)$ & O3-Mn1-N6 & $89.88(8)$ \\
\hline
\end{tabular}

\section{2. X-ray Crystallographic Analysis}

Complex 1 crystallized in the triclinic space group $P \bar{l} . L_{l}$ serves as tridentate chelating ligand, the pyrimidine $\mathrm{N}$-atom from nicotinoylhydrazine is not implicated in complexation. The coordination geometry around the

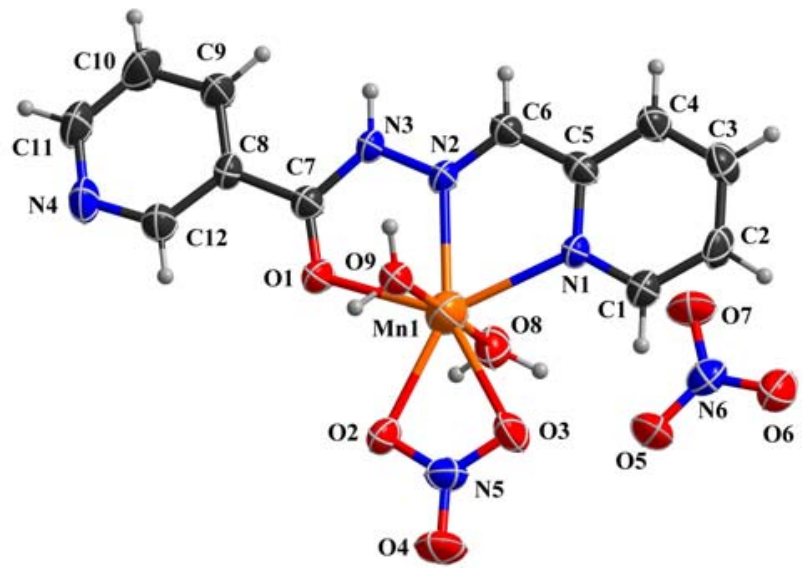

Figure 1. Molecular diagram for complex 1 showing the atom-labeling scheme (non-hydrogen) (50\% thermal ellipsoids)

$\mathrm{Mn}(\mathrm{II})$ center is highly regular pentagonal bipyramid (Figure 1). The equatorial plane is surrounded by two $\mathrm{O}-$ atom donors ( $\mathrm{O} 2$ and $\mathrm{O} 3$ ) from anion $\mathrm{NO}_{3}^{-}$, one carbonyl $\mathrm{O}$-atom $(\mathrm{O} 1)$, one imine $\mathrm{N}$-atom $(\mathrm{N} 2)$ and one pyrimidine $\mathrm{N}$-atom (N1) donors from $L_{1}$, while the axial positions are occupied by $\mathrm{O}$-atom donors (O8 and $\mathrm{O} 9$ ) from two coordinated water molecules. The bond angle of $\mathrm{O} 9-\mathrm{Mn} 1-\mathrm{O} 8$, $177.49(11)^{\circ}$, indicates that the three atoms are in good linear configuration. In addition, the sum of the equatorial angles $\mathrm{O} 1-\mathrm{Mn} 1-\mathrm{N} 2, \quad \mathrm{~N} 2-\mathrm{Mn} 1-\mathrm{N} 1, \quad \mathrm{~N} 1-\mathrm{Mn} 1-\mathrm{O} 3$, O3-Mn1-O2 and O2-Mn1-O1 for complex $1\left(\approx 360.09^{\circ}\right)$ is very close to the ideal value $\left(360.00^{\circ}\right)$, which ensures the planarity of equatorial plane. The axial $\mathrm{Mn}-\mathrm{O}$ average distance $(2.188 \AA)$ is shorter than the equatorial $\mathrm{Mn}-\mathrm{O}$ average distance $(2.329 \AA)$ and $\mathrm{Mn}-\mathrm{N}$ average distance $(2.300 \AA)$, showing the squashed bipyramid surrounding the $\mathrm{Mn}$ (II) center. Compared with the salen-Mn complexes, the $\mathrm{Mn}-\mathrm{O}_{\text {carbonyl }}$ bond length $(2.354(3) \AA$ ) is obviously longer than the $\mathrm{Mn}-\mathrm{O}_{\text {phenolate }}$ bond length (1.850(2) $\AA),{ }^{20}$ and $\mathrm{Mn}-\mathrm{N}_{\text {imine }}$ bond length $(2.267(3) \AA)$ in complex $\mathbf{1}$ is also longer than that in salen-Mn complexes. ${ }^{20,21}$

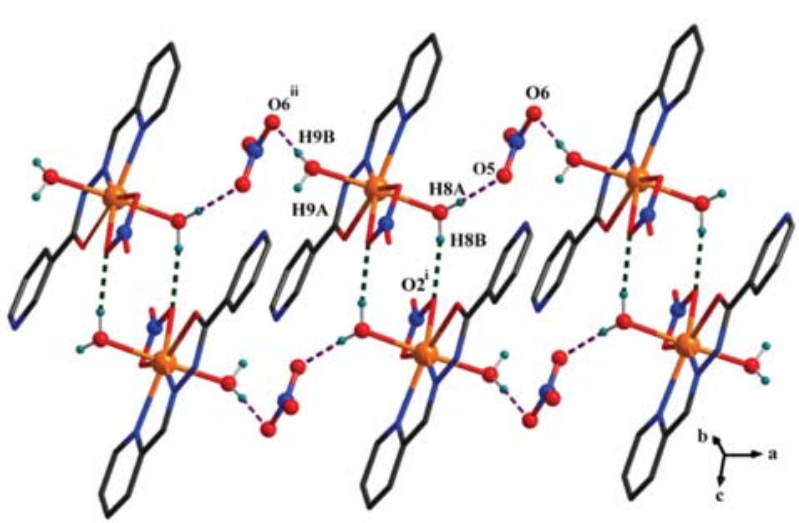

Figure 2. The hydrogen-bond-driven 1D chain extended in crystallographic $a$ axis of $\mathbf{1}$. [Symmetry codes: (i) $-x+1,-y,-z+1$; (ii) $x$ $-1, y, z]$ 
Since the anionic moieties $\mathrm{NO}_{3}^{-}$possess the hydrogen bond acceptors ${ }^{22}$ and the water molecules possess the hydrogen bond donors, ${ }^{23}$ complex 1 presents enhanced hydrogen-bonding framework in the solid state (Table 3). The adjacent mononuclear cations are seized together through the strong hydrogen bonding interactions (O8-H8B $\cdots \mathrm{O} 2^{\mathrm{i}}$, symmetry code: (i) $-x+1,-y,-z+1$ ) between coordinated water molecules and $\mathrm{NO}_{3}^{-}$into a 8-

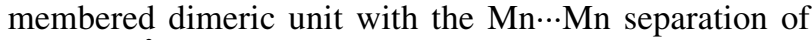
5.407(1) $\AA$. As shown in Figure 2, the free nitrate anions are located between these dimeric units, and serve as hydrogen bonding acceptor linking these dinuclear units into infinite double-chain structures along $a$ axis via

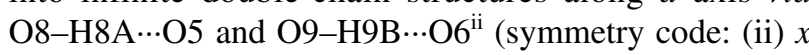
$-1, y, z$ ) hydrogen bonds. These supramolecular chains stack in a face-to-face fashion in $a c$ plane, the hydrogen

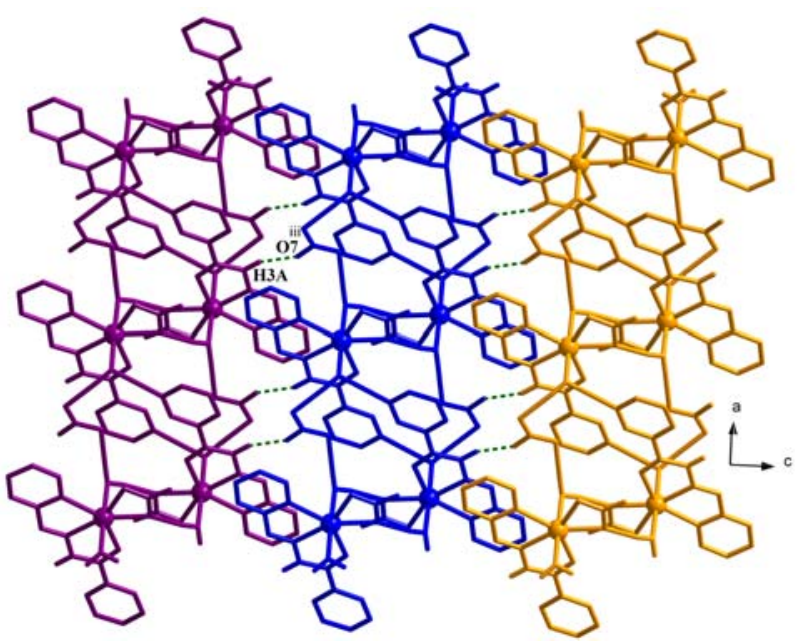

Figure 3. The hydrogen-bond-driven 2D sheet of 1 extended in crystallographic ac plane. [Symmetry codes: (iii) $-x+1,-y,-z$ ] bonds exist between the amido group of ligand $L_{l}$ and the oxygen atom of free nitrate to form an intermolecular $\mathrm{N} 3-\mathrm{H} 3 \mathrm{~A} \cdots \mathrm{O} 7^{\mathrm{iii}}$ (symmetry code: (iii) $-x+1,-y,-z$ ) hydrogen bonding interaction, leading to the construction of 2D supramolecular sheet in the ac plane (Figure 3).

The idea behind the use of ligand $L_{2}$ is to control supramolecular motifs through a 4-pyridine-type ligand. It is known that the relative different orientation of the nitrogen donors on the pyridyl rings could result in unusual building blocks, which can lead to the construction of versatile supramolecular motifs. Crystallization of $L_{2}$ with $\mathrm{Mn}\left(\mathrm{NO}_{3}\right)_{2}$ for the self-assembly reaction in the $\mathrm{CH}_{2} \mathrm{Cl}_{2} / \mathrm{EtOH}$ solvent system afforded $\left[\mathrm{Mn}\left(L_{2}\right)_{2}\left(\mathrm{NO}_{3}\right)\right.$ $\left.\left(\mathrm{H}_{2} \mathrm{O}\right)\right] \mathrm{NO}_{3}$ (2). Complex 2 also crystallized in triclinic

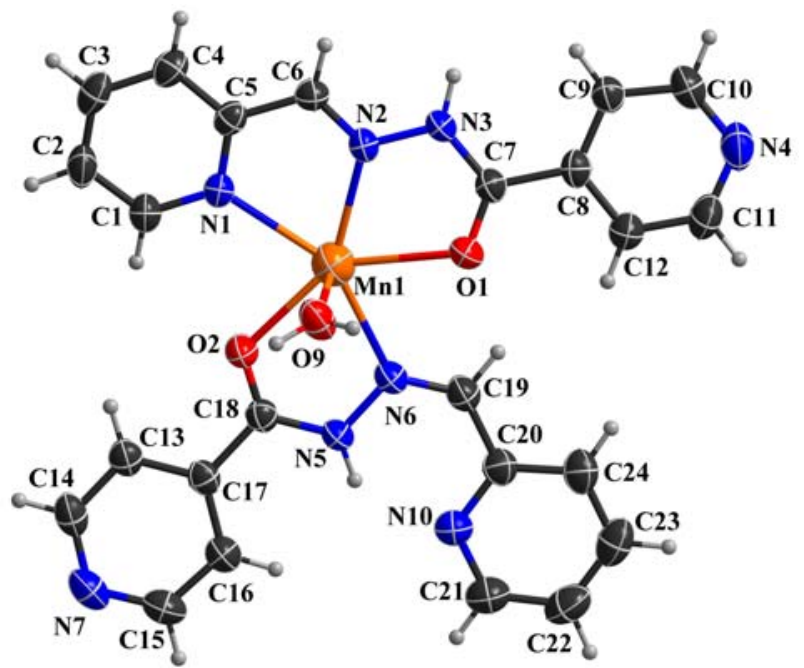

Figure 4. Molecular diagram for complex 2 showing the atom-labeling scheme (non-hydrogen, $\mathrm{NO}_{3}^{-}$are omitted for clarity) $(50 \%$ thermal ellipsoids).

Table 3. Geometrical parameters for hydrogen bonds

\begin{tabular}{|c|c|c|c|c|}
\hline Hydrogen bonds & D-H $(\AA)$ & $\mathbf{H} \cdots A(\AA)$ & $\mathrm{D} \cdots A(\AA)$ & D-H $\cdots A\left(\left(^{\circ}\right)\right.$ \\
\hline \multicolumn{5}{|c|}{ Complex 1} \\
\hline$\overline{\mathrm{O} 8-\mathrm{H} 8 \mathrm{~B} \cdots \mathrm{O} 2^{\mathrm{i}}}$ & $0.850(10)$ & $1.918(11)$ & $2.762(4)$ & 172(4) \\
\hline O9-H9B $\cdots$ O6 $^{\mathrm{ii}}$ & $0.845(10)$ & $2.008(14)$ & $2.846(4)$ & $171(5)$ \\
\hline $\mathrm{N} 3-\mathrm{H} 3 \mathrm{~A} \cdots \mathrm{O} 7^{\mathrm{iii}}$ & 0.89 & 1.92 & $2.778(4)$ & 160.3 \\
\hline O8-H8A $\cdots \mathrm{O} 5$ & $0.845(10)$ & $2.065(12)$ & $2.905(5)$ & $173(4)$ \\
\hline
\end{tabular}

\begin{tabular}{|c|c|c|c|c|}
\hline \multicolumn{5}{|c|}{ Complex 2} \\
\hline$\overline{\mathrm{O} 9-\mathrm{H} 9 \mathrm{~B} \cdots \mathrm{N} 7^{\text {iv }}}$ & 0.84 & 1.96 & $2.801(3)$ & 171.7 \\
\hline O9-H9A $\cdots \mathrm{O}^{\mathrm{v}}$ & 0.85 & 2.31 & $3.134(4)$ & 163.6 \\
\hline O9-H9A $\cdots \mathrm{O}^{\mathrm{v}}$ & 0.85 & 2.33 & $2.929(3)$ & 127.7 \\
\hline $\mathrm{N} 3-\mathrm{H} 3 \mathrm{~A} \cdots \mathrm{O} 7^{\mathrm{vi}}$ & $0.888(10)$ & $2.049(11)$ & $2.930(3)$ & $172(2)$ \\
\hline N5-H5A $\cdots$ N10 & $0.887(10)$ & $1.908(19)$ & $2.619(3)$ & $136(2)$ \\
\hline
\end{tabular}

Symmetry transformations used to generate equivalent atoms: (iv) $-x+1,-y+1,-z$; (v) $-x+1,-y+1,-z+1$; (vi) $-x+2,-y+1,-z+1$ 
space group $P \bar{l}$. An ORTEP view of $\mathbf{2}$ together with the atom numbering scheme is given in Figure 4. The complex $\mathbf{2}$ also showed pentagonal bipyramid geometry with a slight distortion as evidenced from the sum of five equatorial angles of $361.74^{\circ}$ compared to the ideal value of $360^{\circ}$ for planar geometry, and the axial O9-Mn1-O3 angle of $164.05(8)$ is also smaller than the ideal value of $180^{\circ}$. The $\mathrm{Mn}-\mathrm{O}$ bond distance $(2.228(2)--2.4148(16) \AA$ ) and Mn-N bond distance (2.2894(18)-2.3915(18) $\AA$ ) are comparable to those found in complex 1 .

It is worthwhile to point out that the two $L_{2}$ ligands around the Mn center in complex $\mathbf{2}$ are crystallographic different. In one ligand, $L_{2}$ acts as tridentate $N N O$ pincer type chelators, the $\mathrm{C} 7=\mathrm{N} 3$ bond defines the $E$-isomeric form where the two pyridine rings are trans to each other with the dihedral angle of $15.52(6)^{\circ}$. While in the second $L_{2}$ ligand, the two pyridine rings are $c i s$ to each other corresponding to $\mathrm{C} 19=\mathrm{N} 6$ bond, the dihedral angle between them is only $4.21(6)^{\circ}$. In this case, $L_{2}$ acts as bidentate $N O$ chelating ligand.
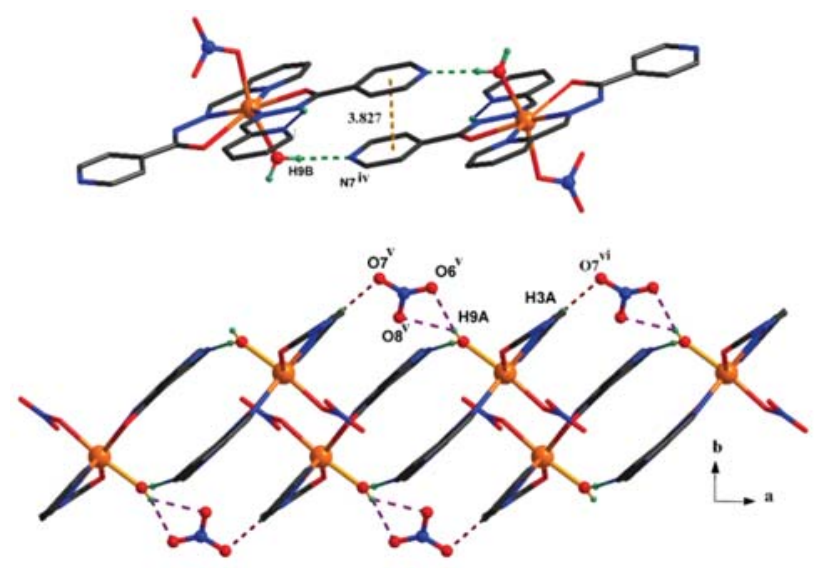

Figure 5. (a) The dimer structure of 2. (b) The hydrogen-bond-driven $1 \mathrm{D}$ chain extended in crystallographic $a$ axis of $\mathbf{2}$. [Symmetry codes: (iv) $-x+1,-y+1,-z$; (v) $-x+1,-y+1,-z+1$; (vi) $-x+2$, $-y+1,-z+1]$

The crystal packing of complex $\mathbf{2}$ is stabilized by means of hydrogen bonding (Table 3 ) in combination with $\pi-\pi$ stacking interactions. Similar to complex $\mathbf{1}$, in complex 2, as shown in Figure 5a, the adjacent molecules are linked through hydrogen bonding interactions to form di-

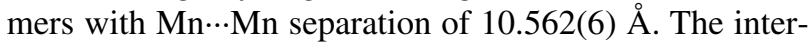
molecular hydrogen bond exists between the hydroxyl group of coordinated $\mathrm{H}_{2} \mathrm{O}$ molecules and nitrogen atom of pyridine ring (O9-H9B $\cdots \mathrm{N}^{\mathrm{iv}}$, symmetry code: (iv) $-x+$ $1,-y+1,-z)$. Meanwhile, the centroid-to-centroid separation of two parallel pyridyl rings is found to be $3.827 \AA$, which indicates moderately strong $\pi-\pi$ interactions. Strong intramolecular hydrogen bonding interactions N5-H5A $\cdots \mathrm{N} 10$ are also observed in the dimer. The uncoordinated nitrate anions are located between these di- meric units, and engaged in hydrogen bonding with coordinated $\mathrm{H}_{2} \mathrm{O}$ molecules $\left(\mathrm{O} 9-\mathrm{H} 9 \mathrm{~A} \cdots \mathrm{O}^{\mathrm{v}}\right.$, O9-H9A $\cdots \mathrm{O}^{\mathrm{v}}$, symmetry code: (v) $-x+1,-y+1,-z+1)$ and amido groups (N3-H3A $\cdots \mathrm{O}^{\mathrm{vi}}$, symmetry code: (vi) $-x+2,-y+$ $1,-z+1)$, giving rise to the double-chain supramolecular structure of complex 2 along $a$ axis (Figure 5b).

\section{3. IR Spectroscopy}

The spectra of complexes $\mathbf{1}$ and $\mathbf{2}$ exhibit broad bands at 3350 and $3383 \mathrm{~cm}^{-1}$, respectively, which can be attributed to $v(\mathrm{OH})$ of the crystallized water molecules, and sharp peaks at 1556 and $1553 \mathrm{~cm}^{-1}$, respectively, due to $\mathrm{H}-\mathrm{O}-\mathrm{H}$ bending vibrations. ${ }^{24}$ The characteristic $v(\mathrm{NH})$ stretches are shown at $3220 \mathrm{~cm}^{-1}$ for $\mathbf{1}$ and 3178 $\mathrm{cm}^{-1}$ for $2 .{ }^{25}$ The sharp absorption bands of $\mathrm{NO}_{3}^{-}$in $\mathbf{1}$ are clearly visible at 1381 and $823 \mathrm{~cm}^{-1}$, while in 2 are at 1384 and $850 \mathrm{~cm}^{-1} \cdot{ }^{26}$ In the complexes $\mathbf{1}$ and $\mathbf{2}$, the involvement of the carbonyl $\mathrm{O}$ and azomethine $\mathrm{N}$ in coordination with $\mathrm{Mn}$ atom weakens the $\mathrm{C}=\mathrm{O}$ band and $\mathrm{C}=\mathrm{N}$ bond leads to the $v(\mathrm{C}=\mathrm{O})$ and $v(\mathrm{C}=\mathrm{N})$ towards lower frequencies in the region of ca. $1648 \mathrm{~cm}^{-1}$ and $1598 \mathrm{~cm}^{-1}$, respectively. ${ }^{24}$

\section{4. SOD Mimetic Property}

Interest in $\mathrm{Mn}(\mathrm{II})$ complexes has been amplified due to their application in biology, ${ }^{15,27}$ e.g., Mn-MRI (magnetic resonance imaging) contrast, Mn-fluorescence agent, and $\mathrm{Mn}$-SOD biomimetics. In previous reports, Mn(II) complexes of pentagonal bipyramidal geometry are functional mimics of SOD. ${ }^{14,15,28}$ In this paper, we studied the SOD mimetic activity of complexes $\mathbf{1}$ and $\mathbf{2}$. The reported manganese complexes with various organic ligands (such as macrocyclic penta-amine, tripodal polyimidazole, diSchiff base) showed $\mathrm{IC}_{50}$ values rank from 0.30 to 35 $\mu \mathrm{M} .{ }^{14,29}$ In our study, $\mathbf{1}$ and $\mathbf{2}$ possess moderate activity of dismutation of superoxide with $\mathrm{IC}_{50}$ values of 32.5 and $21.0 \mu \mathrm{M}$, respectively. The $\mathrm{IC}_{50}$ values reported here are much larger than those of $\mathrm{Mn}$ (II) complex generated from di-Schiff base ligand $(2.85 \mu \mathrm{M}) .{ }^{14}$ This one order of magnitude difference may be ascribe to the rigid planar structure of $\mathbf{1}$ and $\mathbf{2}$, which possess small tendency to fold. ${ }^{28}$ Therefore the $\mathrm{Mn}(\mathrm{II})$ center is constrained in a geometry that limits fast electron-transfer, i.e., a pseudo octahedral geometry preferred by $\mathrm{Mn}(\mathrm{III})$.

\section{Conclusion}

In summary, nicotinoylhydrazine and isonicotinoylhydrazine were used to synthesize hydrazone Schiff base ligands $L_{1}$ and $L_{2}$. Further coordination reactions of these ligands with $\mathrm{Mn}\left(\mathrm{NO}_{3}\right)_{2}$ afforded mononuclear complexes $\mathbf{1}$ and 2, respectively. Although $L_{1}$ and $L_{2}$ are potential $N N N O$ tetradentate ligands, in complexes $\mathbf{1}$ and $\mathbf{2}$, 
they serve as $N N O$ tridentate or $N O$ bidentate chelating ligands. The N-donors free of coordination are engaged in constructing supramolecular architecture. This study demonstrates that the orientation of $\mathrm{N}_{\text {pyridine }}$ and hydrogen bonding patterns of nitrate anions play an important role in constructing unusual supramolecular compounds. Both of the two complexes exhibit moderate SOD mimetic activity.

\section{Supplementary Information}

CCDC files 1023096 (1) and 1023097 (2) contain the supplementary crystallographic data for this paper. These data can be obtained free of charge from The Cambridge Crystallographic Data Centre via www.ccdc.cam. ac.uk/data_request/cif.

\section{Referance}

1. A. Escuer, B. Cordero, M. Font-Bardia, T. Calvet, Inorg. Chem. 2010, 49, 9752-9754. http://dx.doi.org/10.1021/ic101636r

2. Y. B. Dong, X. Zhao, R. Q. Huang, Inorg. Chem. 2004, 43, 5603-5612. http://dx.doi.org/10.1021/ic049787a

3. R. Vafazadeh, M. Alinaghi, A. C. Willis, A. Benvidi, Acta Chim. Slov. 2014, 61, 121-125.

4. D. S. Kalinowsk, P. C. Sharpe, P. V. Bernhardt, D. R. Richardson, J. Med. Chem. 2008, 51, 331-344. http://dx.doi.org/10.1021/jm7012562

5. M. X. Li , L. Z. Zhang, D. Zhang, B. S. Ji, J. W. Zhao, Eur. J. Med. Chem. 2011, 46, 4383-4390. http://dx.doi.org/10.1016/j.ejmech.2011.07.009

6. P. G. Cozzi, Chem. Soc. Rev. 2004, 33, 410-421. http://dx.doi.org/10.1039/b307853c

7. T. Katsuki, Chem. Soc. Rev. 2004, 33, 437-444. http://dx.doi.org/10.1039/b304133f

8. H. Keypour, M. Shayesteh, M. Rezaeivala, F. Chalabian, Y. Elerman, O. Buyukgungor, J. Mol. Struct. 2013, 1032, 62-68. http://dx.doi.org/10.1016/j.molstruc.2012.07.056

9. D. Barut, N. Korkmaz, S. T. Astley, M. Aygün, Acta Chim. Slov. 2015, 62, 88-94.

10. S. Mondal, S. Naskar, A. K. Dey, E. Sinn, C. Eribal, S. R. Herron, S. K. Chattopadhyay, Inorg. Chim. Acta 2013, 398, 98-105. http://dx.doi.org/10.1016/j.ica.2012.12.018

11. P. S. Mukherjee, S. Dalai, E. Zangrando, F. Lloret, N. R. Chaudhuri, Chem. Commun. 2001, 1444-1445. http://dx.doi.org/10.1039/b104649g
12. D. B. Dang, H. Gao, Y. Bai, X. J. Pan, W. L. Shang, J. Mol. Struct. 2010, 969, 120-125. http://dx.doi.org/10.1016/j.molstruc.2010.01.051

13. D. Salvemini, C. Muscoli, D. P. Riley, S. Cuzzocrea, Pulm. Pharmacol. Ther. 2002, 15, 439-447. http://dx.doi.org/10.1006/pupt.2002.0374

14. X. M. Ouyang, B. L. Fei, T. Okamura, W. Y. Sun, W. X. Tang, N. Ueyama, Chem. Lett. 2002, 362-363. http://dx.doi.org/10.1246/cl.2002.362

15. D. P. Riley, Chem. Rev. 1999, 99, 2573-2587. http://dx.doi.org/10.1021/cr980432g

16. Y. F. Liu, Y. P. Liu, K. K Zhang, Q. L. Ren, J. Qin, Acta Cryst. 2015, C71, 116-121.

17. Bruker, SMART and SAINT, Bruker AXS Inc., Madison, Wisconsin, USA. 2002.

18. G. M. Sheldrick, SADABS, Program for Empirical Absorption Correction of Area Detector, University of Göttingen, Germany 1996.

19. G. M. Sheldrick, Acta Crystallogr. A 2008, 64, 112-122. http://dx.doi.org/10.1107/S0108767307043930

20. C. N. Chen, D. G. Huang, X. F. Zhang, F. Chen, H. P. Zhu, Q. T. Liu, C. X. Zhang, D. Z. Liao, L. C. Li, L. C. Sun, Inorg. Chem. 2003, 42, 3540-3548. http://dx.doi.org/10.1021/ic025944z

21. H. L. Shyu, H. H. Wei, Y. Wang, Inorg. Chim. Acta 1999, 290, 8-13. http://dx.doi.org/10.1016/S0020-1693(99)00089-4

22. R. Custelcean, B. A. Moyer, V. S. Bryantsev, B. P. Hay, Cryst. Growth Des. 2006, 6, 555-563. http://dx.doi.org/10.1021/cg0505057

23. J. Qin, L. Cui, Inorg. Chem. Commun. 2013, 36, 170-173. http://dx.doi.org/10.1016/j.inoche.2013.08.034

24. A. A. El-Sherif, M. R. Shehata, M. M. Shoukry, M. H. Barakat, Spectrochim. Acta A 2012, 96, 889-897. http://dx.doi.org/10.1016/j.saa.2012.07.047

25. S. Mondal, S. Naskar, A. K. Dey, E. Sinn, C. Eribal, S. R. Herron, S. K. Chattopadhyay, Inorg. Chim. Acta 2013, 398, 98-105. http://dx.doi.org/10.1016/j.ica.2012.12.018

26. J. Qin, N. Lei , H. L. Zhu, J. Coord. Chem. 2014, 67, 1279 1289. http://dx.doi.org/10.1080/00958972.2014.909591

27. K. S. Dube, T. C. Harrop, Dalton Trans. 2011, 40, 74967497. http://dx.doi.org/10.1039/c1dt10579e

28. K. Aston, N. Rath, A. Naik, U. Slomczynska, O. F. Schall, D. P. Riley, Inorg. Chem. 2001, 40, 1779-1789 http://dx.doi.org/10.1021/ic000958v

29. M. P. Clares, S. Blasco, M. Inclán, L. del C. Agudo, B. Verdejo, C. Soriano, A. Doménech, J. Latorre, E. García-España, Chem. Commun. 2011, 47, 5988-5990. http://dx.doi.org/10.1039/c1cc10526d 


\section{Povzetek}

Dva nova liganda, potencialno štirivezni Schiffovi bazi, $N^{\prime}$-(piridin-2-ilmetilen)nikotinohidrazide $\left(L_{l}\right)$, in $N^{\prime}$-(piridin-2ilmetilen)izonikotinohidrazid $\left(L_{2}\right)$ sta bila sintetizirana. Pri reakciji hidrazonskega liganda $L_{1}$ oziroma $L_{2} \mathrm{z} \operatorname{Mn}\left(\mathrm{NO}_{3}\right)_{2}$ nastaneta dva enojedrna $\mathrm{Mn}(\mathrm{II})$ kompleksa, $\left[\mathrm{Mn}\left(L_{1}\right)\left(\mathrm{NO}_{3}\right)\left(\mathrm{H}_{2} \mathrm{O}\right)_{2}\right] \mathrm{NO}_{3}(\mathbf{1})$ in $\left[\mathrm{Mn}\left(L_{2}\right)_{2}\left(\mathrm{NO}_{3}\right)\left(\mathrm{H}_{2} \mathrm{O}\right)\right] \mathrm{NO}_{3}(\mathbf{2})$. Pri spojinah 1 in 2 sta $L_{1}$ in $L_{2}$ tri- oziroma dvovezna liganda. Centralna Mn(II) iona sta v obeh spojinah heptakoordinirana, supramolekularna struktura v kristalu pa je pri spojinah zelo različna zaradi različne orientacije $\mathrm{N}_{\text {piridin }}$ in vodikovih vezi, v katerih sodeluje nitratni anion. Struktura 1 vsebuje 2D supramolekularne plasti, medtem ko ima struktura 2 motiv dvojne verige. Obe spojini izkazujeta zmerno superoksid dismutasno (SOD) mimetično aktivnost. 